\title{
TRANSFORMASI PERILAKU MASYARAKAT BERAGAMA DALAM KABUPATEN BATANGHARI JAMBI
}

\author{
Ishak Abd. Aziz
}

Fakultas Ushuluddin dan Studi Agama UIN STS Jambi ishaqabdulazis@gmail.com

\begin{abstract}
This study highlights the phenomenon of changes in adolescent behavior in the Batanghari District. This research is limited to exploring the phenomenon of the transformation of religious values of the people in Batanghari Regency. After conducting this research, several things were found, namely; The forms of transformation of religiosity values in Batanghari Regency are grouped into three categories, namely mild categories such as lying, staying up late, going out without greetings, skipping school, fighting with friends, fighting, and littering. While the moderate category is speeding, drinking, gambling, and picking pockets. Whereas for the heavy categories include drug abuse, extramarital sex, and pornography. The factors that cause the transformation of values are identity crisis, pride when they break the rules, and weak control. The response of Batanghari District residents to the phenomenon of silencing the value of religiosity is to take preventive, curative, and repressive actions.

Penelitian ini menyoroti fenomena perubahan perilaku remaja tersebut di lingkup Kabupaten Batanghari. Penelitian ini dibatasi untuk menggali fenomena transformasi nilai keagamaan masyarakat di Kabupaten Batanghari. Setelah melakukan penelitian ini, ditemukan beberapa hal yakni; Bentuk-bentuk transformasi nilai religiusitas di Kabupaten Batanghari dikelompokkan menjadi tiga katagori yaitu kategori ringan seperti berbohong, begadang, pergi keluar rumah tanpa salam, membolos sekolah, berkelahi dengan teman, tawuran, dan membuang sampah sembarangan. Sedangkan kategori sedang adalah kebut-kebutan, minum-minuman keras, berjudi, dan mencopet. Sedangkan untuk kategori berat diantaranya penyalahgunaan narkoba, hubungan seks di luar nikah, dan pornografi. Faktor penyebab terjadinya transformasi nilai tersebut adalah krisis identitas, adanya rasa bangga ketika dapat melanggar aturan, serta kontrol yang lemah. Respon warga Kabupaten
\end{abstract}

TAJDID Vol. 17, No. 2, Juli - Desember 2018|129 
Batanghari terhadap adanya fenomena pendangkalan nilai religiusitas tersebut adalah melakukan tindakan yang bersifat preventif, kuratif, dan represif.

Keywords: Transformasi, Nilai Religius, Masyarakat, Budaya, Ekologi, Moral

\section{Pendahuluan}

Transformasi adalah sebuah proses perubahan secara berangsur-angsur sehingga sampai pada tahap ultimate, perubahan yang dilakukan dengan cara memberi respon terhadap pengaruh unsur eksternal dan internal yang akan mengarahkan perubahan dari bentuk yang sudah dikenal sebelumnya melalui proses menggandakan secara berulang-ulang atau melipatgandakan. Habraken (1976) mengatakan bahwa transformasi merupakan; (1) Kebutuhan identitas diri (identification) pada dasarnya orang ingin dikenal dan ingin memperkenalkan diri terhadap lingkungan; (2) Perubahan gaya hidup (life style) perubahan struktur dalam masyarakat, pengaruh kontak dengan budaya lain dan munculnya penemuan-penemuan baru mengenai manusia dan lingkuangannya; (3) Pengaruh teknologi baru timbulnya perasaan ikut mode, dimana bagian yang masih dapat dipakai secara teknis (belum mencapai umur teknis dipaksa untuk diganti demi mengikuti mode).

Ekologi budaya adalah sebuah cara pandang memahami persoalan lingkungan hidup dalam perpektif budaya. Atau sebaliknya, bagaimana memahami kebudayaan dalam perspektif lingkungan hidup. Ulang-alik antara lingkungan hidup (ekologi) dan budaya itulah yang menjadi bidang garapan dari ekologi budaya, atau disingkat elbud. Ekologi budaya muncul sebagai hasil kerja (Carl Sauer) pada geografi dan pemikiran dalam antropologi. Ekologi budaya mempelajari bagaimana manusia beradaptasi dengan lingkungan alamnya. Suatu ciri dalam ekologi budaya adalah perhatian mengenai adaptasi pada dua tataran, yaitu: 
Pertama, sehubungan dengan cara sistem budaya berdaptasi terhadap lingkungan totalnya. Kemudian, yang kedua, sebagai konsep adaptasi sistemik, perhatian terhadap cara institusi-institusi dalam suatu budaya baradaptasi dan saling menyesuaikan diri. Ekologi budaya menyatakan bahwa diperlukannya proses-proses adaptasi akan memungkinkan untuk melihat cara kemunculan, pemeliharaan dan transformasi sebagai konfigurasi budaya.

Parsons dalam Wahyu menyebutkan keseimbangan dalam sistem sosial dianalisis dalam 4 (empat) hukum, yaitu: (1) Prinsip kelembagaan yang menegaskan kelanggengan laju dan arah suatu peroses kecuali bila kekuatan pendorong yang berlawanan menimpa proses itu; (2) Prinsip aksi reaksi yafng menegaskan bahwa setiap perubahan arah suatu proses akan diimbangi oleh prubahan lain yang kekuatan pendorongnya dan keuatan dari arah berlawanannya adalah setara; (3) Prinsip upaya yang menyatakan bahwa perubahana dalam laju proses sebanding dengan besarnya kekuatan pendorong yang digunakan atau yang diambil; dan (4) Prinsip sistim integrasi yang menegaskan bahwa nasib unsur unsur satu pola tergantung pada nilai unsur tersebut selaku faktor pemersatu (pengintegrasi). ${ }^{1}$

Steward menyebutkan bahwa manusia memiliki corak yang khas dan unik, salah satunya adalah proses perkembangan kebudayaan. Proses perkembangannya di berbagai belahan bumi tidak terlepas antara satu dan lainnya; dan bahkan ada beberapa diantaranya yang tampak sejajar terutama pada sistem mata pencaharian hidup, sistem kemasyarakatan, dan sistem religi. Hal ini dikarenakan perkembangan yang sejajar di daerah tertentu. Misalnya pada masyarakat berburu; ada kecenderungan mereka hidup di lingkungan alam yang sulit dengan binatang buruan yang hidup terpencar. Agar ia mendapat binatang buruan, mereka harus benar-benar mengenal lingkungan alam tempat mereka berburu.

${ }^{1}$ Wahyu, Rakyat Sosial (Jakarta: Rajawali Press, 2005), hlm. 16-17

TAJDID Vol. 17, No. 2, Juli - Desember 2018 $\mid 131$ 
Untuk itu mereka harus hidup berklompok. Karenanya kalau mereka harus mengambil wanita untuk dikawini,mereka harus membawa gadis itu ke dalam kelompoknya.

Demikian halnya pada kalangan masyarakat yang telah mengenal system pertanian. Tatkala jumlah penduduk sedikit dan tanah masih sangat luas, mereka harus hidup terpencar dalam desa-desa kecil. Apabila jumlah penduduk semakin banyak maka akan terjadi kekurangan tanah sehingga orang tidak lagi dapat begitu saja meninggalkan ladang mereka yang sudah tidak subur. Orang akan terpaksa mengerjakan bidang tanah untuk kurun waktu yang lama. Pertanian irigasi telah menimbulkan pengelompokan manusia dalam desa-desa kecil yang saling berpencar dan semakin lama desa itu menjadi semakin besar. Pertanian menetap membuat orang mengolah tanahnya secara intensif karena itu munculah teknologi-teknologi seperti bajak dan pemanfaatan binatang sebagai pengganti tenaga manusia. Akibatnya terbentuklah struktur masyrakat pada bentuk baru, dan akhirnya berkembang pula irigasi untuk mengolah tanah yang tidak subur. Timbullah system irigasi dengan organisasi dan orang-orang mengatur irigasi dan muncul pula pelapisan masyarakat. Mereka yang mengatur irigasi menjadi yang berkuasa sehingga muncullah adat yang mengatur antara orang yang berkuasa dengan anggota masyarakat.

Pada perkembangannya kemudian, semakin lama kehidupan mereka semakin kompleks. Sementara itu di kalangan masyarakat juga terjadi atau muncul berbagai jenis pekerjaan, demikian dan seterusnya. Untuk itu diperlukan aturan yang mengatur hubungan di antara masyarakat. Demikian ekologi budaya membicarakan interaksi bentuk-bentuk kehidupan dalam suatu ekosistem tertentu dan membahas cara manusia membentuk ekosistem itu sendiri.

Kehidupan individu dan masyarakat akan selalu berhadapan dengan perubahan karena manusia akan melengkapi kebutuhan dalam proses kehidupannya, misalnya kebutuhan dasar manusia, 
keamanan, sosial, pengakuan, prestasi dan sebagainya. Semua kebutuhan menurut Wahyu hanya akan dicapai melalui dan akan ditentukan oleh lingkungan sosial yang lebih maju dan baik. Seperti ekonomi pedesaan yang maju akan mampu mengubah wajah pedesaan yang lebih maju, harga karet yang mahal akan menciptakan masyarakat makmur, perairan di sekitar mereka juga mampu meningkatkan kesejahteraan masyarakat karena sumber yang ada di dalamnya akan mampu meningkatkan pendepatan masyarakat. Contohnya, ikan akan memberi asupan gizi dan pendapatan masyarakat, pasir dan batu untuk bahan bangunan juga akan mampu meningkatkan pendapatan masyarakat. ${ }^{2}$

Menurut Cohen (1983) sebagaimana dikutip oleh Wahyu dijelaskan bahwa apabila perubahan sosial terjadi dengan sangat cepat, efek-efek negatifnya juga sangat besar. Efek negatif dari perubahan antara lain individu-individu menjadi merasa asing, kesepian, dan putus asa, apalagi kalau perubahan itu terjadi secara mendadak. Ia bisa mengacaukan dan menggoyahkan perasaan individu. Jika efek itu menyebabkan terjadinya kesenjangan kultur, mungkin sekali akan terjadi disorganisasi umum di dalam masyarakat secara keseluruhan sebab biasanya perubahan sosial itu sering dibarengi oleh bermacam-macam problem. ${ }^{3}$

Gudykunst dan Kim mengatakan bahwa "Proses adaptasi antar budaya melibatkan interaksi terus menerus dari dekulturasi dan akulturasi budaya yang membawa perubahan pada orang asing (imigran) ke arah asimilasi, tingkat tertinggi dari adaptasi secara teoritis dapat dibayangkan." ${ }^{4}$ Soejono Soekanto secara garis besar menjelaskan sumber perubahan sosial yang berasal dari dalam masyarakat/internal dan luar masyarakat/eksternal. Faktor Internal; perubahan kependudukan, penemuan, konflik dalam

${ }^{2}$ Ibid., hlm. 24

${ }^{3}$ Ibid., hlm. 25

${ }^{4}$ Gudykunst dan Kim, A First Look At Communication Theory (United States: McGraw-Hills, 2003), hlm. 360

TAJDID vol. 17, No. 2, Juli - Desember 2018|133 
masyarakat, terjadinya pemberontakan atau revolusi. Faktor eksternal ini meliputi antara lain, peperangan dengan negara lain, pengaruh kebudayaan masyarakat lain, perubahan dari lingkungan alam fisik yang ada di sekitar manusia. ${ }^{5}$

Menurut Schorl (1980), modernisasi adalah proses penerapan ilmu pengetahuan dan teknologi ke dalam semua segi kehidupan manusia dengan tingkat yang berbeda-beda tetapi tujuan utamanya untuk mencari tarap hidup yang lebih baik dan nyaman dalam arti yang seluas-luasnya, sepanjang masih dapat diterima oleh masyarakat yang bersangkutan. Modenisasi dapat terwujud melalui beberpa syarat, yaitu: (1) Cara berpikir ilmiah yang institusionalized baik kelas penguasa mauapun masyarakat; (2) System administrasi negara yang baik yang benar-benar mewujud birokrasi; (3) Adanya pengumpulan system pengumpulan data yang baik dan teratur yang terpusat pada suatu atau lembaga tertentu; (4) Penciptaan iklim yang baik dan teratur dari masyarakat terhadap modernisasi dengan penggunaan alat komunikasi massa; (5) Tingkat organisasi yang tinggi, yaitu adanya pembagian kerja, efesiensi dan efektifitas kerja; (6) Adanya keseimbangan antara sentralisasi dan desentralisasi. ${ }^{6}$

Ciri-ciri Modenisasi adalah sebagai berikut: (1) Naturitas kebutuhan material dan ajang persaingan kebutuhan manusia; (2) Kemajuan teknologi dan industrialisasi, individualisasi, sekularisasi, diferensiasi, dan akulturasi; (3) Modern banyak memberi kemudahan bagi manusia; (4) Berkat jasanya, hampir semua keinginan manusia terpenuhi; (4) Modernisasi juga memberikan melahirkan teori baru; (6) Mekanisme masyarakat berubah menuju prinsip dan logika ekonomi serta orientasi kebendaan yang

${ }^{5}$ Soerjono Soekanto, Sosiologi: Suatu Pengantar (Jakarta: Rajawali Press, 1992), hlm. 23

${ }^{6}$ Ibid.

134 | TAJDID Vol. 17, No. 2, Juli - Desember 2018 
berlebihan; (7) Kehidupan seorang perhatian religiusnya dicurahkan untuk bekerja dan menumpuk kekayaan. ${ }^{7}$

Penelitian awal penulis menemui beberapa fenomena dalam masyarakat Batanghari, yaitu: (1) Pergeseran budaya dalam kehidupan bermasyarakat, diantaranya hilang nilai-nilai masyarakat kumunal, seperti dalam melestarikan alam, menjaga kebersihan lingkungan, memelihara sumber-sumber kehidupan alami, bersikap saling pengertian, mendahulukan orang lain yang lemah dan tak berdaya, berempati, bersimpati, menghormati keharmonisan dan keselarasan serta keramahan; (2) Masyarakat cenderung individualis, dan materialis; (3) Timbul sikap hegemoni dalam masyarakat, mayarakat diperalat dan ditekan untuk mendapat suatu kekuasaan, hal ini terjadi dalam pemilu legislatif, pilkada, dan pemilu; dan (4) Pengajian keagamaan, seperti mengaji ke rumah guru-guru agama atau alim ulama sudah tidak dilakukan lagi; dan (5) minat orang tua atau wali murid untuk menyekolah anak-anak mereka ke madrasah rendah. ${ }^{8}$

Berdasarkan fakta-fakta di atas, maka peneliti tertarik untuk melakukan penelitian secara komprehensif dengan judul: "Transformasi Perilaku Masyarakat Beragama dalam Kabupaten Batanghari Jambi."

\section{Konsep Transformasi Budaya}

Transformasi secara etimologis memiliki dua makna yaitu: (1) Perubahan rupa (bentuk, sifat, fungsi, dan lain sebagainya) dan (2) Perubahan struktur gramatikal menjadi struktur gramatikal lain dengan menambah, mengurangi, atau menata kembali unsurunsurnya. ${ }^{9}$ Secara etimologis, budaya adalah (1) Pikiran, akal budi;

${ }^{7}$ Ibid.

${ }^{88}$ Observasi tanggal 01 Agusus 2017

${ }^{9}$ Dandy Sugono, Kamus Besar Babasa Indonesia (Jakarta: Gramedia Pustaka, 2014), hlm. 1484

TAJDID vol. 17, No. 2, Juli - Desember 2018|135 
(2) Adat istiadat, (3) Sesuatu mengenai kebudayaan yang sudah berkembang (beradab. maju), (4) Sesuatu yang sudah menjadi kebiasaan dan sudah menjadi kebiasaan dan sukar dirubah. ${ }^{10}$ Kebudayaan adalah semua hasil karya, rasa, dan cipta manusia. ${ }^{11}$ Dengan demikian, kebudayaan atau budaya menyangkut keseluruhan aspek kehidupan manusia baik material maupun nonmaterial. Kebudayaan material antara lain hasil cipta, karsa,yang berwujud benda, barang alat pengolahan alam, seperti gedung, pabrik, jalan, rumah, dan sebagainya. Sedangkan kebudayaan nonmaterial merupakan hasil cipta, karsa yang berwujud kebiasaan, adat istiadat, ilmu pengetahuan dan sebagainya.

Transformasi budaya secara teoritis diartikan sebagai suatu proses dialog yang terus-menerus antara kebudayaan lokal dengan kebudayaan "donor" sampai tahap tertentu membentuk proses sintesa dengan berbagai wujud yang akan melahirkan format akhir budaya yang mantap. Dalam proses dialog, sintesa, dan pembentukan format akhir tersebut didahului oleh proses inkulturisasi dan akulturasi. Transformasi diperlukan dalam rangka menuju modernisasi, yang merupakan serangkaian perubahan nilai-nilai dasar yang meliputi nilai teori, nilai sosial, nilai ekonomi, nilai politik (kuasa), nilai estetika, dan nilai agama. ${ }^{12}$

\section{Konsep Perubahan Sosial Budaya}

Perubahan sosial-budaya adalah sebuah gejala berubahnya struktur sosial dan pola budaya dalam suatu masyarakat.

${ }^{10}$ Dandy Sugono, Kamus Besar Bahasa Indonesia (Jakarta: Gramedia Pustaka, 2014), hlm. 214

${ }^{11}$ Abu Ahmadi, Antropologi Budaya (Surabaya: Pelangi, 1986), hlm. 84

${ }^{12}$ Jujun S. Suriasumantri dalam Eti Ismawati, Ilmu Seni Budaya Dasar (Yogyakarta: Ombak, 2012), hlm. 100

136 | TAJDID Vol. 17, No. 2, Juli - Desember 2018 
Perubahan sosial budaya merupakan gejala umum yang terjadi sepanjang masa dalam setiap masyarakat. Perubahan itu terjadi sesuai dengan hakikat dan sifat dasar manusia yang selalu ingin mengadakan perubahan. Menurut Geertz, perubahan sosialbudaya dapat terjadi karena adanya faktor dari dalam kebudayaan itu sendiri, dalam artian para pendukungnya merasa bahwa beberapa perantara kebudayaannya harus dirubah dan disesuaikan dengan perkembangan objek di dalam kehidupan sosialnya. ${ }^{13}$ Perubahan sosial-budaya juga dapat terjadi dari luar kebudayaan itu sendiri karena adanya pengaruh kebudayaan lain yang secara lambat laun mempengaruhi kebudayaan tersebut. Terutama dapat terjadi karena adanya kontak-kontak kebudayaan dengan pendukung kebudayaan lain (akulturasi).

\section{Konsep Perubahan Perilaku}

Secara etimologis, kata "perubahan" berasal dari kata dasar "ubah." Adapun kata ubah tersebut diartikan sebagai: tukar atau ganti. ${ }^{14}$ Sedangkan kata perubahan diartikan sebagai: (1) Hal (keadaan) berubah; peralihan; pertukaran, atau (2) Perbaikan aktiva tetap yang tidak menambah jumlah jasanya. ${ }^{15}$ Berdasarkan dua makna dari kata perubahan di atas, maka arti yang pertama lebih mengena dalam konteks penelitian ini. Dari banyak teori yang ada, teori Homans mengenai perilaku sosial dianggap paling tepat untuk memahami perubahan-perubahan perilaku yang terjadi pada masyarakat melalui adanya tradisi Mandi Safar di Desa Air Hitam Laut yang dilakukan setiap tahun. Homans menekankan dasar perilaku manusia adalah karena pertukaran (exchange), di mana perilaku sosial (social behavior) sebagai dasar keberadaan manusia sebagai anggota satu komunitas. Turner menjelaskan bahwa

${ }^{13}$ Nasaruddin Suyuti, 0, hlm. 22

${ }^{14}$ Dandy Sugono, Kamus Besar Bahasa Indonesia (Jakarta: Gramedia Pustaka Utama, 2014), hlm. 1514

${ }^{15}$ Ibid.

TAJDID Vol. 17, No. 2, Juli - Desember 2018|137 
konsep dasar Homans mengenai perubahan perilaku adalah melalui delapan tahapan sebagai berikut: (1) Stimulus; (2) Action; (3) Reward; (4) Punishment; (5) Value; (6) Cost; (7) Perception; dan (8) Expectation.

\section{Bentuk-bentuk Transformasi Religiusitas di Kabupaten Batanghari}

Berdasarkan data di lapangan, yakni di Kabupaten Batanghari dapat disajikan hasil penelitian tentang pendangkalan nilai religiusitas masyarakatnya dengan membuat tiga klasifikasi yaitu: 1 . pendangkalan nilai religius ringan, 2. Pendangkalan nilai religius sedang, dan 3. Pendangkalan nilai religius berat. Menurut hasil observasi dan wawancara dengan Bapak Zainal Abidin selaku Tokoh Masyarakat di Kabupaten Batanghari, bahwa masalah bentuk-bentuk transformasi religiusitas menuju kearah pendangkalan nilai agama yang terjadi di kalangan masyarakat Kabupaten Batanghari ini lebih banyak mengarah kepada pendangkalan nilai religius ringan (seperti berkelahi, membolos sekolah, tidak mengucapkan salam ketika masuk dan keluar rumah, terlibat minum-minuman keras, dan sebagainya). Namun demikian, ada pula sebagian masyarakat yang melakukan perbuatan dalam katergori pendangkalan nilai religius tingkat sedang dan berat sehingga masuk dalam kategori tindakan pidana, namun kategori ini tidak seberapa jumlahnya. ${ }^{16}$

Dari penelusuran peneliti di lapangan, banyak peneliti jumpai beberapa hal yang digolongkan sebagai perbuatan yang bertentangan dengan ajaran agama, dan bisa dikategorikan sebagai praktik pendangkalan religius. Berdasarkan pengamatan, wawancara, dan dokumentasi yang peneliti kumpulkan, diperoleh beberapa perilaku yang mengarah kepada pendangkalan nilai religiusitas tersebut. Misalnya perilaku berbohong kepada sesama.

${ }^{16}$ Hasil Observasi tanggal 01 Agustus 2017

138 | TAJDID Vol. 17, No. 2, Juli - Desember 2018 
Berdasarkan observasi peneliti di lapangan, perilaku berbohong tersebut banyak dilakukan oleh masyarakat Kabupaten Batanghari. Fenomena ini peneliti temui setelah melakukan wawancara dengan Romi seorang pelajar SMP di Kabupaten Batanghari mengatakan pernah membohongi orang tuanya sendiri demi mendapatkan uang agar bisa mengajak pacarnya makan-makan pada malam minggu. Berikut keterangan Romi kepada peneliti:

"Saya pernah memang berbohong kepada orang tua. Pada waktu itu, saya kepepet karena pacar saya ingin mengajak saya keluar jalan-jalan pada malam minggu. Biasalah anak mudo (muda). Namun saya bingung bagaimana cari modal, karena pasti ngajak (mengajak) makan-makan, kan (bukankah) saya malu kalau tidak ada persiapan dana. Waktu otak saya pusing, tidak tahu lagi bagaimana caranya, akhirnya terbetike (terlintas) di hati saya untuk berbohong kepada Ibu untuk meminta uang iuran sekolah. Padahal memang waktu itu tidak ada pembayaran uang iuran sekolah. Saya terpaksa berbohong demi kebahagiaan pacar saya supaya mau diajak jalan-jalan." 17 Berdasarkan wawancara di atas diketahui bahwasanya perilaku berbohong merupakan perilaku yang sudah sering terjadi dan dilakukan oleh para pelajar di Kabupaten Batanghari. Bahkan alasan berbohong itu pun juga tidak jelas, yaitu hanya sekedar untuk berpacaran dan menghambur-hamburkan uang.

Berdasarkan observasi peneliti pada hari yang lain, ditemukan adanya kebiasaan para pemuda di Kabupaten Batanghari tersebut untuk begadang. Aktivitas ini selalu terjadi hampir setiap malam, kecuali apabila pada malam hari tersebut turun hujan yang cukup deras, maka tidak ditemui para pemuda yang berkumpul di sudut Kabupaten Batanghari. Lokasi tempat mereka begadang ini adalah di halaman warung-warung yang sudah tutup. Mereka kadang

${ }^{17}$ Wawancara, RM Desa Kubu Kandang, Pelajar SMP Jembatan Mas, 05 Agustus 2017,

TAJDID Vol. 17, No. 2, Juli - Desember 2018|139 
berkelompok hingga delapan orang, bercengkerama dengan suara keras dan bising. Hal ni tentu akan menggangu warga lainya yang butuh istirahat. Biasanya para pemuda ini akan membawa serta gitar lalu bernyanyi dengan suara yang keras. Kadangkala disertai minuman beralkohol, dan sampah kacang mereka akan berserakan dimana-mana. Hal ini kadang-kadang dilakukan hingga hampir masuk waktu shalat shubuh. ${ }^{18}$

Berdasarkan hasil wawancara peneliti dengan salah satu pemuda yang ikut serta begadang hingga pagi di Kabupaten Batanghari tersebut mengatakan bahwa kegiatan mereka itu hanyalah sekedar melepas lelah karena seharian bekerja di kebun. Jadi waktu mereka untuk ngumpul hanyalah di malam hari saja. Jadi mereka menganggap bahwa kegiatan mereka itu wajar-wajar saja. Berikut ini komentar Teguh selaku pemuda di Kabupaten Batanghari:

"Menurut sayo (saya), kegiatan kami ko dak katek (tidak ada) yang salah. Inilah kesempatan kami ngumpul (berkumpul), kalu (kalau) pagi sampe (sampai) siang kami kerjo (kerja), jadi malam kayak ikolah (seperti inilah) baru sempat kami berkumpul sesame (bersama) kawan-kawan lainnyo (lainnya). Sekedar hiburan. Kan dak (bukankah tidak) merugikan orang lain jugo (juga), kami cuma pingin senang be (saja) melepas capek (lelah)." ${ }^{19}$

Berdasaran wawancara di atas diketahui bahwa dalam pandangan pemuda Kabupaten Batanghari, kegiatan mereka itu adalah kegiatan hiburan yang mereka anggap tidak ada yang keliru dengan perbuatan begadang itu. Dari sini sudah cukup jelas bahwa sebagian pemuda tersebut tidak mengerti dan tidak memiliki pengetahuan serta konsep diri bagaimana cara bertindak yang benar dan dibolehkan dari masyarakat dan mana yang tidak boleh dan melampaui batas. Peneliti juga berkesempatan melakukan

\footnotetext{
${ }^{18}$ Hasil Observasi tanggal 07 Agustus 2017

${ }^{19}$ Wawancara, TH Desa Selat, Pemuda Desa Selat, 06 Agustus 2017,
}

140 | TAJDID Vol. 17, No. 2, Juli - Desember 2018 
wawancara dengan salah seorang Ibu Rumah Tangga (IRT) di Kabupaten Batanghari yaitu Nela Asniati yang merupakan staff Lurah Kabupaten Batanghari yang menuturkan bahwa anaknya NV yang sedang duduk dibanguku SMA jika keluar masuk rumah sudah jarang sekali mengucapkan salam. Hal ini menjadi kegelisahan tersenidir bagi Ibu Nela tersebut. Berikut penuturan beliau:

"Agak susah untuk sekarang ini, karena jamanya udah berbeda ya. Anak saya yang di SMA sekarang itu sulit sekali rasanya untuk memberikannya pengertian. Sudah berapa kali saya mengingatkan untuk memberikan salam kalau mau masuk dan keluar rumah, tetapi agak sulit bang (abang). Anak saya itu cuma sekedar nyelonong (masuk tanpa ijin) bae (saja). Mana ngajinya juga jarang sekarang. Apalgi semenjak ada acara D2 Academy dangdut di Indosiar, aduh susah mau ngajinya lepas Maghrib itu." ${ }^{, 20}$ Berdasarkan wawancara tersebut di atas diketahui bahwasanya kegiatan pengajian anak remaja Ibu Nela menajdai terganggu akibat dari kemajuan teknologi dan tayangan hiburan yang komersial di televisi. Sehingga anak kehilangan kesadaran diri untuk mengisi waktu Maghrib tersebut dengan kegiatan mengaji al-Quran.

Peneliti menemukan pula perilaku pendangkalan religiusitas remaja adalah mereka yang membolos ketika masuk jadwal shalat dzuhur berjaman di sekolahnya. Dan hal ini selalu terjadi dan dilakukan oleh sebahagian pelajar yang berasal dari SMA di Kabupaten Batanghari. Mereka terlihat selalu bergerombolan minimal empat orang. Mereka loncati pagar sekolah dan pulan sebelum jadwal bel pulang berbunyi.. informasi ini peneliti peroleh dari remaja pelaku bolos sekolah tersebut. Berikut ini penuturanya kepada peneliti:

\footnotetext{
${ }^{20}$ Wawancara, NA Desa Selat, Staff Lurah Desa Selat, 09 Agustus 2017
}

TAJDID Vol. 17, No. 2, Juli - Desember 2018 $\mid 141$ 
"Saya paling dak biso nian (tidak bisa) ikutan shalat berjamaah di sekolah pak. Karna saya ada jadwal main game online sama kawan-kawan di warnet. Kalau saya dak (tidak) cepat balek (pulang), nanti kawan-kawan malah semakin jauh dan tidak mau bergaul dengan saya. Saya lebih milih persahabatan kami pak. Karna kalau shalat kan bisa di rumah jugo (juga). Dak apolab (tidak mengapa) minggat." ${ }^{21}$ Senada dengan apa yang dinyatakan oleh HI di atas, DW juga menyatakan kepada peneliti bahwa ia juga pernah minggat dari sekolah ketika jadwal shalat dzuhur berjamaah di sekolah. Menurutnya ia tidak selalu minggat. Hanya jika ia sedang dalam kondisi tidak shalat saja ia minggat. Ia tidak senang untuk menunggu di sekolah walaupun di absen. Hal ini ia lakukan karena ia bosan kalau harus menunggu, dan lagi ia juga tidak shalat jadi, lebih baik ia pulang duluan. Berikut penuturan DW kepada peneliti:

"Saya memang pernah minggat bang (abang) waktu jam shalat Zhuhur berjamaah, tapi kan dak (bukankah tidak) selalu bang (abang). Hanya kalau lagi dapat bae (menstruasi saja). Kan (bukankah) bosan kalau harus nunggu (menunggu) di lapangan, sementara yang lain sholat. Jadi saya milih balek bae (pulang saja). Daripada buang-buang waktu."22 Berdasarkan wawancara di atas diketahui bahwasanya DW memilih untuk minggat daripada menunggu jadwal shalat berjamaah usai dan absen kehadiran dilaksanakan. Karena menurt dia hal itu sangat membosankan. Berdasarkan pengamatan peneliti, kejadian ini memang masih banyak dilakukan oleh para siswa-siswa SMA dari Kabupaten Batanghari lainya. Misalnya yang mengikuti DW minggat saja biasanya adala lima orang teman-temanya. ${ }^{23}$

${ }^{21}$ Wawancara, HI Dusun Ture, Kecamatan Pemayung, Pelajar SMA Pijoan, 11 Agustus 2017

${ }^{22}$ Wawancara, DW Desa Pulau Betung, Pelajar SMA Pijoan, 12 Agustus 2017

${ }^{23}$ Hasil Observasi tanggal 12 Agustus 2017

142 |TAJDID Vol. 17, No. 2, Juli - Desember 2018 


\section{Faktor Penyebab Terjadinya Pendangkalan Nilai Religiusitas}

Dalam kehidupan masyarakat, semua tindakan manusia dibatasi oleh aturan (norma) untuk berbuat dan berperilaku sesuai dengan sesuatu yang dianggap baik oleh masyarakat. namun demikian, di tengah-tengah kehidupan masyarakat, termasuk di Dusun Ujung Tanjung masih dijumpai tindakan-tindakan yang tidak sesuai dengan aturan (norma) yang berlaku pada masyarakat. Kedangkalan religiusitas yang terjadi di Kabupaten Batanghari khususnya yang terjadi dikalangan para remajanya disebabkan oleh faktor psikologis yang berakar pada persoalan lingkungan di mana remaja tersebut tinggal. Hal ini, sebagaimana dinyatakan oleh Ibu Syamsinar A.B kepada peneliti sebagai berikut:

"Begini ya, dalam pandangan Ibu, kondisi religiusitas di Kabupaten Batanghari ini cukup memprihatinkan. Ibu menjumpai kadangkala ada remaja baik laki-laki maupun perempuan sudah tidak segan-segan lagi duduk berboncengan di atas motor dengan mesra, padahal mereka belum ada ikatan pertunangan apalagi pernikahan. Padahal, pada masa Ibu remaja dahulu sampai kirakira tahun 2000-an kondisi sopan santun masyarakat dan remaja di sini masih cukup baik. Menurut Ibu, hal ini terjadi karena adanya faktor lingkungan. Anak muda zaman sekarang ini merasa bangga kalau sudah bisa membawa perempuan kulu kilir (hilir mudik). Pokoknya hebatlah tu (itu) dalam pemahaman mereka."24 Berdasarkan wawancara di atas, diketahui bahwa perasaan bangga dalam melakukan tindakan yang kurang sopan bahkan dilarang dalam agama Islam, seperti berdua-duan dengan yang bukan mahram-nya ternyata bersumber dari perasaan bangga pada diri remaja tersebut. Hal ini juga dipahami sama oleh Bapak Zainal Abidin yang menuturkan kepada peneliti sebagai berikut:

${ }^{24}$ Wawancara, AB Desa Lopak Aur, Pengelola PAUD Kecamatan Pemayung, 01 Agustus 2017

TAJDID vol. 17, No. 2, Juli - Desember $2018 \mid 143$ 
"Kalau menurut bapak, perilaku yang kurang elok (beradab), idak mandang orang tuo (tidak memandang orang tua) lagi, memang sudah macam inilah kenyatannyo (kenyataannya). Apolagi nengok mudo-mudi kini tu (apalagi melihat pemuda-pemudi sekarang ini), memang dari segi pergaulan menurut bapak sudah kelewatan. Cuman kan (hanya saja) perilaku yang dangkal semacam ini kan (bukankah) ado (ada) dua macam. Yaitu tidak disenagaja dan disengaja. Kalu (kalau) pandangan bapak, kini tu (saat ini) remaja di dusun ini tu memang sengajo nianlah (secara sengaja) melakukan perbuatan dak elok (tidak baik) ini, yang melanggar agamo kito (agama kita) Islam ini. Bukan karena tidak tahu, tetapi budak (anak) itu tahulah aturan, malah anak sekolahan pulak (pula). Cuman mungkin kareno (karena) orang itu ingin diperhatikan, cari sensai dan sebagainyalah."25

Berdasarkan wawancara di atas diketahui bahwa ternyata pendangkalan nilai religiusitas dikalangan remaja di Kabupaten Batanghari itu terjadi dengan kesadaran bahwa perilaku itu memang salah dalam perspektif agama. Asusmsi ini muncul karena berdasarkan pengamatan peneliti di lapangan, memang perbuatanperbuatan yang menunjukkan kedangkalan religiusitas tersebut justeru dilakukan oleh remaja yang berpendidikan seperti pada level sekolah menengah. ${ }^{26}$ Bapak Desman juga menambahkan pendapatnya mengenai faktor penyebab terjadinya pendangkalan religiusitas di Kabupaten Batanghari ini khususnya dikalangan remaja dikarenakan adanya krisis identitas pada diri remaja itu sendiri. Berikut pernyataan beliau kepada peneliti:

"Menurut bapak, kelompok pemuda di Kabupaten Batanghari ini memang kelihatanya sudah kehilangan jati diri. Mereka tidak mengenal siapa diri mereka dan kemana mereka akan melangkah.

${ }^{25}$ Wawancara, H. Ilyas, Tokoh Masyarakat Imam Masjid Lopak Aur, 02 Feburari 2017

${ }^{26}$ Hasil Observasi tanggal 03 Agustus 2017

144 | TAJDID vol. 17, No. 2, Juli - Desember 2018 
Dalam pandangan bapak, yah mereka ini seperti anak-anak saja, dan kegiatan mereka hanya bermain tanpa ada usaha untuk mencari kegiatan positif atau bekerja sambilan untuk meringankan beban orang tua mereka masing-masing., ${ }^{\text {,27 }}$ Berdasarkan data wawancara di atas, diketahui bahwa pendangkalan nilai religiusitas terjadi akibat dari adanya krisis identitas. Berdasarkan observasi peneliti di lapangan, hal ini terjadi sebagai akibat adanya teori yang mengatakan bahwa terjadinya pendangkalan religiusitas terjadi karena krisi identitas yang bersumber pada situasi remaja, dimana remaja tersebut mulai terbentuknya perasaan dari seorang remaja tersebut selalu ingin disebarluaskan dalam kehidupan sehari-hari, dan adapun yang kedua adalah mulai tumbuhnya identitas peran.

Berdasarkan pengamatan peneliti di lapangan, pendangkalan religiusitas di Kabupaten Batanghari ini khususnya dikalangan remaja ini disebabkan oleh kurangnya kontrol diri. ${ }^{28}$ Terkait akan informasi ini, peneliti peroleh setelah melakukan wawancara dengan $\mathrm{H}$. Komaruddin yang menuturkan kepada peneliti sebagai berikut:

"Remaja di Kabupaten Batanghari ini sepengetahuan bapak tidak bisa membedakan tingkah laku yang pantas dengan yang tidak pantas. Malah kadang-kadang itu, yang tahu itu tidak pantas pun masih dilanggarnya. Barangkali mereka ini anak-anak yang tidak bisa mengontrol diri untuk konsisten dengan tingkah laku yang baik yang sudah dia ketahui itu. Sehingga kalau ada rayuan dari temanya untuk main dom (domino) misalnya, sudah lah itu, maka merekapun langsung berkumpul main dom (domino) di warung sampai larut malam." 29 Berdasarkan wawancara di atas diketahui bahwa pemahaman dan kesadaran akan perilaku yang

${ }^{27}$ W awancara, Darsono, Lurah Sungai Buluh Kabupaten Batanghari, 04 Agustus 2017

${ }^{28}$ Hasil Observasi tanggal 05 Agustus 2017

${ }^{29}$ Wawancara, Karim, Imam Masjid Bajubang Barat, Kabupaten Batanghari, 06 Agustus 2017

TAJDID vol. 17, No. 2, Juli - Desember 2018|145 
tidak baik dan pengaruh dari teman sebaya memberikan kontribusi terhadap transformasi ke arah pendangkalan nilai religiusitas khususnya di kalangan remaja Kabupaten Batanghari.

Berdasarkan pengamatan peneliti di lapangan, kasus-kasus pendangkalan nilai religiusitas yang terjadi di Kabupaten Batanghari tersebut juga terjadi disebabkan sudah tidak berjalanya lagi aktivitas pengajian remaja dan anak yang biasanya ada dilaksanakan di dua buah rumah di Kabupaten Batanghari. Hal ini secara langsung dan tidak langsung juga mempengaruhi munculnya pendangkalan nilai religiusitas di Kabupaten Batanghari tersebut. Informasi ini peneliti peroleh bedasarkan penuturan salah seorang tokoh masyarakat di Kabupaten Batanghari sebagai berikut:

"Saat ini saya cukup prihatin melihat keadaan anak-anak muda di Kabupaten Batanghari ini. Mereka sangat jauh sekali akhlaknya jika dibandingkan dengan zaman bapak dahulu. Kalau zaman bapak dulu pengaiian maghrib isya itu rutin dilakukan. Tapi kondisinya untuk sekarang ini sudah jauh berbeda. Entahlah. Sejak tahun 2013-an sampai sekarang ini pengajian sudah dak (tidak) berjalan lagi. Magrib isya sudah diisi dengan kegiatan yang bertentangan dengan ajaran agama. Ini barangkali ado kaitanyo (ada kaitannya) juga dengan tidak berjalanya lagi kegiatan mengaji maghrib isya di rumah-rumah warga." 30 Menurut peneliti, pendangkalan nilai religiusitas juga disebabkan oleh perceraian orang tua, atau perselisihan antar anggota keluarga juga bisa memicu perilaku immoral remaja. Pendidikan yang salah di keluarga pun seperti terlalu memanjakan anak, tidak memberikan pendidikan agama yang cukup kepada anak atau penolakan

${ }^{30}$ Wawancara, Muhammad Amin Bulian, Imam Masjid Kabupaten Batanghari, 06 Agustus 2017

146 | TAJDID Vol. 17, No. 2, Juli - Desember 2018 
terhadap anak juga dapat bertanggung jawab terhadap munculnya pendangkalan religiusitas di kalangan remaja. ${ }^{31}$

\section{Dampak Transformasi Nilai Religiusitas Masyarakat di Kabupaten Batanghari}

Setiap perbuatan selalu membawa dampak baik untuk dirinya maupun yang berkaitan dengan lingkungan di sekitarnya demikian pula dengan penyimpangan perilaku nilai-nilai religiusitas. Beberapa hal yang berkaitan dengan akibat atau dampak yang ditimbulkan dari adanya pendangkalan nilai-nilai religiusitas tersebut adalah:

\section{Dampak Psikis (Kebahagiaan Hidup)}

Tidak seorangpun yang tidak ingin menikmati ketenangan hidup. Setiap masyarakat Kabupaten Batanghari pastilah ingin mencarinya.meskipun tidak semua dapat tercapai apa yang diinginkanya. Perilaku yang mencerminkan pendangkalan nilai religiusitas yang terjadi di Kabupaten Batanghari dapat mengakibatkan hilangnya ketenteraman dan kedamaian hidup. Suasana hati tersebut sangat jauh dari tujuan syariat Islam yang tujuan utamanya ingin dicapai oleh metode Islam dalam jaminan sosial adalah menghilangkan kasus-kasus pencurian, penyalahgunaan, menggerakkan kasih sayang sehingga tercipta keharmoisan dalam lingkungan masyarkat tersebut.

\section{Dampak Terhadap Intelektualitas}

Banyak penelitian mengatakan bahwa keturunan atas kecerdasan dapat diwarisi (dipengaruhi) oleh kecerdasan orang tuanya (ibu bapaknya) akan tetapi jika tidak mendapatkan kesempatan dan lingkungan yang baik untuk berkembang, maka kecerdasan tidak akan mencapai kemampuan yang maksimal.

\footnotetext{
${ }^{31}$ Hasil Observasi tanggal 05 Agustus 2017
}

TAJDID Vol. 17, No. 2, Juli - Desember 2018|147 
Timbulnya pendangkalan nilai religiusitas di Kabupaten Batanghari tentunya bukan saja akan berdampak kepada keresahan masyarakat akan tetapi juga berdampak kepada kemampuan sebahagian warga Kabupaten Batanghari itu sendiri dalam proses kedewasaan berpikir. Sehubungan dengan hal tersebut usia informan kunci sehubungan dengan hal tersebut delikuensi pada remaja sangat berpengaruh terhadap kecerdasan mereka misalnya kebiasaan terhadap minuman keras, mengonsumsi narkoba, senang membawa gambar porno, yang menggambarkan kesan yang kuat terhadap kehidupan yang serba bebas. Keadaan pendangkalan nilai religius sedemikian rupa biasanya dikarenakan kurang mengutamakan atau mementingkan belajar. Informan kunci yang peneliti amati biasanya acuh tak acuh terhadap tugas sekolah dan kehilangan rasa tanggung jawab di dalamnya. Kepentingan dalam mencerdaskan diri menjadi hilang karena mereka disibukkan dengan tingkah laku yang membuat dirinya terjerumus pada dunia kebebasan, sehingga banyak remaja yang terlibat dalam dunia bebas tersebut menjadi pemalas belajar dan bodoh, sehingga tidak bias membedakan konsep perbuatan yang sesuai atau tidak sesuai dengan perintah agama. ${ }^{32}$

\section{Dampak Terhadap Kesehatan Jasmaniah}

Banyak perilaku pendangkalan nilai yang sudah terjadi misalnya saja mengkonsumsi narkoba, minuman keras, perkelahian dan tawuran itu semua dapat membawa dampak negative bagi kesehatan jasmani pelaku. Karena hal tersebut merupakan perbuatan yang tidak manusiawi mengingat tidak hanya melukai bahkan dapat saja mengancam keselamatan jiwa. ${ }^{33}$

\footnotetext{
${ }^{32}$ Hasil Observasi tanggal 26 Agustus 2017

${ }^{33}$ Hasil Observasi tanggal 27 Agustus 2017
}

148 | TAJDID Vol. 17, No. 2, Juli - Desember 2018 


\section{Respon Masyarakat Batanghari terhadap Transformasi Nilai Religiusitas}

Berdasarkan pengamatan peneliti di lapangan, respon masyarakat Kabupaten Batanghari terhadap fenomena pedagkalan nilai religiusitas yang terjadi di dusun tersebut terbagi kepada tiga macam yaitu respon preventif, respon kuratif, dan respon represif.

\section{Respon Preventif}

Keresahan yang diakibatkan dari adanya pendangkalan nilai religiusitas yang terjadi di Kabupaten Batanghari sebenarnya sudah menjadi tanggung jawab seluruh anggota masyarakat Kabupaten Batanghari itu sendiri. Jika ditinjau dari segi penyebabnya, masyarakat terlibat di dalmnya dan jika dilihat dari segi lain, masyarakat itu sendiri pulalah yang memikul beban kerugian akibat fenomena pendangkalan nilai religiusitas di Kabupaten Batanghari itu sendiri. ${ }^{34}$ Akan tetapi dalam menanggulangi kasus pendangkalan nilai religiusitas tersebut tidaklah sama dengan mengobati suatu penyakit. Hal ini disebabkan karena pendangkalan nilai religiusitas merupakan persoalan yang kompleks dan banyak ragam serta jenisnya penyebabnya.

Oleh sebab itu respon yang diberikan tidak bias hanya mengandalkan tenaga ahli saja seperti psikolog dan pendidik, melainkan perlu kerjasama denan semua pihak antara lain guru, orang tua, lembaga pendidikan, pemerintah, masyarakat tenaga ahli dan pelaku pendangkalan nilai religiusitas itu sendiri. ${ }^{35}$ Sehubungan dengan hal tersebut maka usaha penanggulangan pendangkalan nilai religiusitas tersebut perlu dilakukan dengan tahapan pencegahan sebelum hal tersebut semakin meluas dan menular kepada generasi-generasi penerus di Kabupaten Batanghari tersebut.

\footnotetext{
${ }^{34}$ Hasil Observasi tanggal 01 September 2017

${ }^{35}$ Hasil Observasi tanggal 02 September 2017
} 
Usaha preventif adalah segala tindakan yang bertujuan mencegah timbulnya kenakalan dan pendangkalan nilai religiusitas usaha pencegahan ini bias dilakukan secara sistematis terencana dan terarah kepada tujuan untuk menjaga agar pendangkalan nilai religiusitas itu tidak terjadi. Usaha secara preventif lebih besar manfaatnya karena sebelum pendangkalan nilai religiusitas itu meluas dan mempengaruhi waga masyarakat Kabupaten Batanghari yang lain, maka fenoemna tersebut sudah dapat ditekan semaksimal mungkin. Adapun langkah-langkah yang dimaksudkan dalam arti preventif ini adalah sebagaimana penuturan Bapa Lurah kepada peneliti sebagai berikut:

"Kito lah berusaho (kita sudah berusaha) dengan cara meningkatkan kesejahteraan masyarakat, kita kerjasama dengan pemda untuk membuat program-program kelompok tani, memberikan bantuan pupuk, sehingga mereka dapat penghasilan yang cukup, dan dengan demikian warga tidak ada yang potong kompas dengan cara berjudi untuk mendapatkan uang. Kemudian kita dari kelurahan berkunjung ke dusun-dusun yang miskin, yang terkenal banyak terjadi aktivitas perjudian, yah kita kerjasama juga

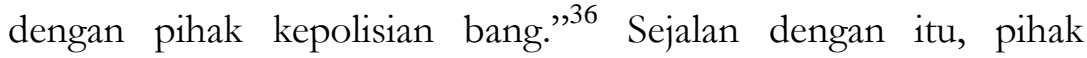
kelurahan juga telah berkoordinasi dengan tokoh masyarakat setempat mengenai solusi preventif untuk mengurangi tindakan pendangkalan nilai religiusitas tersebut. Upaya yang dilakukan adalah bermusyarah untuk membentuk peraturan desa dengan tujuan memberikan sanksi kepada warga di dusun-dusun yang melakukan kegiatan immoral tersebut. Akan tetapi perencanaan ini masih belum dapat diterapkan karena masih dalam tahapan proses perancangan.

"Pihak pemerintah rasanya juga sudah mulai ada arah-arah untuk membentuk peraturan desa (perdes) rencananya itu akan

${ }^{36}$ Wawancara, Saman, Lurah Desa Terusan, Kabupaten Btanghari, 02 September 2017

150 | TAJDID Vol. 17, No. 2, Juli - Desember 2018 
diberlakukan tahun ini, Cuma memang masih dalam tahapan perundingan dengan tokoh-tokoh masyarakat di setiap dusun. Usulan ini muncul dari pihak dusun yang merasa sudah resah dengan aksi perjudian dan miras di dusun mereka. Makanya tokoh masyarakat sampai ada yang mencoba mengusulkan perdes untuk mencegah ini terjadi dan meluas." ${ }^{, 37}$ Dari wawancara di atas, diketahui bahwa dampak dari fenomena pendangkalan nilai di Kabupaten Batanghari ini sudah sangat meresahkan warga masyarakat yang lainya. Hal ini terbukti dengan dihasilkanya usulan untuk membentuk perdes. Iutu artinya perilaku pendangkalan nilai religiusitas yang terjadi sudah tidak bisa ditoleransi lagi dan telah terbuka di depan umum.

\section{Kesimpulan}

Bentuk-bentuk transformasi nilai religiusitas di Kabupaten Batanghari dikelompokkan menjadi tiga katagori yaitu kategori ringan seperti berbohong, begadang, pergi keluar rumah tanpa salam, keluyuran, membolos sekolah, berkelahi dengan teman, tawuran, dan membuang sampah sembarangan. Sedangkan kategori sedang adalah kebut-kebutan, minum-minuman keras, berjudi, dan mencopet. Sedangkan untuk kategori berat diantaranya penyalahgunaan narkoba, hubungan seks di luar nikah, dan pornografi. Faktor penyebab terjadinya transformasi nilai tersebut adalah krisis identitas, adanya rasa bangga ketika dapat melanggar aturan, serta kontrol yang lemah dari pihak orang tua dan juga aturan desa baik pemerintah maupun adat tidak diberlakukan sepenuhnya lagi. Dampak dari pendangkalan nilai religiusitas adalah sebagai berikut yaitu dampak dari segi psikis (kebahagiaan hidup), dampak terhadap intelektualitas, dampak terhadap kesehatan jasmaniah.

${ }^{37}$ W awancara, Suprapto, Staff Lurah Sridadi, Kabupaten Batanghari, 03 September 2017

TAJDID Vol. 17, No. 2, Juli - Desember 2018|151 
Respon warga Kabupaten Batanghari terhadap adanya fenomena pendangkalan nilai religiusitas tersebut adalah melakukan tindakan yang bersifat preventif, kuratif, dan represif. Tindakan tersebut telah dilakukan oleh lapisan sosial masyarakat di Kabupaten Batanghari mulai dari pendidik, masyarakat, dan pemerintahan.

\section{Daftar Pustaka}

Gudykunst dan Kim, A First Look At Communication Theory. United States: McGraw-Hills, 2003

Soekanto, Soerjono Sosiologi: Suatu Pengantar. Jakarta: Rajawali Press, 1992

Wahyu. Rakyat Sosial. Jakarta: Rajawali Press, 2005

Sugono, Dandy. Kamus Besar Babasa Indonesia. Jakarta: Gramedia Pustaka, 2014

Ahmadi, Abu. Antropologi Budaya. Surabaya: Pelangi, 1986

Suriasumantri, Jujun S. dalam Eti Ismawati, Ilmu Seni Budaya Dasar Yogyakarta: Ombak, 2012

Saebani, Beni Ahmad. Metode Penelitian. Bandung: Pustaka Setia, 2010

Sudican, Setna Yuwana Penuntun Penyusunan Karya Ilmiah. Semarang: Aneka Ilmu, 1998

Wawancara, AB Desa Lopak Aur, Pengelola PAUD Kecamatan Pemayung, 01 Agustus 2017

Wawancara, Darsono, Lurah Sungai Buluh Kabupaten Batanghari, 04 Agustus 2017

Wawancara, DW Desa Pulau Betung, Pelajar SMA Pijoan, 12 Agustus 2017

Wawancara, H. Ilyas, Tokoh Masyarakat Imam Masjid Lopak Aur, 02 Feburari 2017

Wawancara, HI Dusun Ture, Kecamatan Pemayung, Pelajar SMA Pijoan, 11 Agustus 2017

Wawancara, Karim, Imam Masjid Bajubang Barat, Kabupaten Batanghari, 06 Agustus 2017

152 | TAJDID Vol. 17, No. 2, Juli - Desember 2018 